\title{
STUDY ON DIVERSITY OF BEES (HYMENOPTERA, APOIDEA) FROM DIFFERENT REGIONS OF IRAQ
}

\author{
Razzaq Shalan Augul \\ Iraq Natural History Research Center and Museum, University of Baghdad, \\ Baghdad, Iraq \\ Corresponding author: razzaqshalan@gmail.com, \\ dr.rsha@nhm.uobaghdad.edu.iq
}

Received Date: 11 February 2018

Accepted Date:06 March 2018

\begin{abstract}
The fauna of bees (Hymenoptera, Apoidea) from different regions of Iraq is surveyed in this study; there were 16 species, 13 genera that belong to four families which are collected in this investigation.

Also, all the species that are recorded for Iraq in previous investigations are revised; totally there are 110 species, 32 genera belonging to five families: Apidae, Andernidae, Colletidae, Halictidae and Megachilidae were listed.

Key words: Apoidea, Bees, Diversity, Fauna, Hymenoptera, Iraq.

\section{INTRODUCTION}

The higher classification of bees has changed recently; Gauld and Bolton (1988) recognized only two families, Sphecidae and Apidae in the superfamily Apoidea, they classified all bees within Apidae in different subfamilies; whereas Michener (1993) recognized 11 families of bees within an informal series Apiformis of Apoidea: Apidae, Andrenidae, Anthophoridae, Colletidae, Ctenoplectidae, Fidellidae, Halictidae, Megachilidae, Melittidae, Oxaeidae and Stenotritidae; but later reduced the number of families to seven by Michener (2000, 2007), these families included: Melittidae, Megachilidae, Apidae, Andrenidae, Colletidae, Stenotritidae, and Halictidae.

Bees are thought to have played an important role in the diversification of the angiosperms in the early to mid-Cretaceous (Grimaldi, 1999); and also they played a role with other insect's pollination in ecosystem service: fruits, vegetables or seeds production from 87 of the 115 leading global food crops depend upon animal pollination (Klein et al., 2007).

To addition, in agriculture, pollination is an important input of crop production, comparable to any other input such as fertilizers and pesticides; similar to the worldwide values, the only studies that have tried to measure pollination contribution to commodity at national levels also have produced inconsistent values. For example, in the United State of America alone, the value of pollination has been reported to range from US\$ 4.5 billion in the 1960s to US\$18.9 billion in the late 1980s (O'Grady, 1987; Robinson et al., 1989; Morse and Calderone, 2001).
\end{abstract}


In Iraq, previous studies in this concern were very few and scarce, for example, Hassan (2007) studied the pollinators (Apoidea) that pollinated alfalfa plant in Babylon governorate; Augul (2016) conducted a survey of flower pollinators, including the Apiformis from different localities; whereas Ahmed (2017) studied the taxonomic aspects of the species that belong to this guild from northern Iraq. So, the current investigations have been made to survey the wild bee species that belong to series of Apiformis from the different localities, followed by a revised checklist of the species registered in previous studies.

\section{MATERIALS AND METHODS}

The specimens were collected from different parts of Iraq during 2015 and 2017; the whole specimens studied were labeled and stored in the Iraq Natural History Research Center and Museum, University of Baghdad.

The collected specimens were identified to the lowest taxonomic rank using different keys such as: Amiet et al. (2004); Michener (2007); Karunaratne and Edirisinghe (2008); Eardly et al. (2010); Sheffield et al. (2011); Nadimi et al. (2013), in addition, compared with identified species stored in insects collection of Iraq Natural History Research Center and Museum, University of Baghdad to assure the diagnosis.

The Synonymized of name species depended on Sakagami and Ebmer (1987), Ebmer (1988), Pauly (1999), BWARS (2012), Kuhlmann et al. (2015), Salem and El-Azab (2017) and Ascher and Pickering (2018).

\section{RESULTS AND DISCUSSION}

In present investigation, there were 16 species, 13 genera belonging to 4 families, which were collected from different regions of Iraq; also we revised the species registered previously in the checklists as below:

Family, Andrenidae

Andrena albifacies Alfken, 1927

Global distribution: Egypt, Israel, Libya and Iraq (Grace, 2010).

Andrena albopicta Radoszkowski, 1874

Global distribution: Turkey, Iraq and Iran (Grace, 2010).

Andrena cordialis Morawitz, 1877

Global distribution: Iraq (Derwesh, 1965); Greece, Crete and Turkey (Grace, 2010).

Andrena flavipes Panzer, 1799

Materials Examined ( 3 우 specimens): Baghdad province, Al-Madaen, 1, 18.IV.2015. Wasit province: Al-Zubaidiya, 2, 20.X.2017.

Global distribution: Iraq (Derwesh, 1965); Europe, North Africa, Turkey, China, Nepal, India and Uzbekistan (Huan-li and Tadauchi, 2008).

Andrena morio Brullé, 1806

Global distribution: Iraq (Khalaf and Al-Omar, 1974); Germany, Hungary, North Africa and Central Asia (Warncke and Scobiola-Palade, 1980); whereas Grace (2010) listed this species in: Greece, Rhodes, Crete, Cyprus, Turkey, Syria, Lebanon, Egypt, Libya, and Israel. 


\section{Razzaq Shalan Augul}

Andrena sigiella Gusenleitner, 1998

Global distribution: Iraq, Jordan, Syria and Israel (Grace, 2010).

Andrena viridescens Viereck, 1916

=Andrena cyanescens $\mathrm{Nyl}$.

Global distribution: This species is listed to fauna of Iraq by Derwesh (1965) under the synonym of Andrena cyanescens Nyl.; Romania and Central Europe (Warncke and ScobiolaPalade, 1980); Greece and Turkey (Grace, 2010).

Andrena vetula Lepeletier, 1841

Global distribution: Iraq (Derwesh, 1965); Greece, Turkey, Cyprus, Syria, Lebanon, Israel, Palestine, Egypt and Libya (Grace, 2010)

\section{Family: Apidae}

Amegilla albigena (Lepeletier, 1841)

=Anthophora albigena Lep.

Global distribution: In Iraq it was listed by Derwesh (1965) under the name of Lasius (Anthophora) albigena. Greece, Cyprus, Turkey, Syria, Jordan and Egypt (Grace, 2010); Algeria, Armenia, Croatia, Czech Republic, Italy, Spain, Portugal, France, Slovakia, Greece, Macedonia, Uzbekistan, Morocco, Egypt, Afghanistan, India, Iran, Israel, Lebanon, Nepal, Tajikistan and Turkmenistan (Insctoid.Info, 2018).

Amegilla harttigi (Alfken 1926)

Global distribution: Iraq (Grace, 2010) and Saudi Arabia (Ascher and Pickering, 2018).

Amegilla quadrifasciata (de Villers, 1789)

Materials Examined (3 $\bigcirc \bigcirc$ specimens): Wasit province: Aziziyah, 3, 3.X.2017.

Global distribution: Palaearctic region (Baldock, 2014); in Iraq this species was listed by Khalaf and Al-Omar (1974) under the name Anthophora quadrifasciata Vill.

Ancyla holtzi Friese, 1902

Global distribution: Iraq, Greece, Cyprus, Turkey and Iran (Grace, 2010).

Ancyla orientalica Warncke, 1979

Global distribution: Iraq, Greece, Turkey and Syria (Grace, 2010).

Anthophora atriceps (Pérez, 1879)

Global distribution: Iraq (Khalaf and Al-Omar, 1974); Egypt (Grace, 2010); Morocco, Algeria, Syria, Tunisia Iran, Israel, Switzerland (Inectoid.Info, 2018).

Anthophora orientalis Morawitz, 1877

Global distribution: In Iraq, this species was listed by Khalaf and Al-Omar (1974); Croatia, Greece, Italy and Spain (Rasmont and Dehon, 2015 a).

Anthophora salviae (Panzer, 1804)

=Anthophora crinipes Smith, 1854

Global distribution: In Iraq, this species was registered under the name Anthophora crinipes Smith, 1854 by Khalaf (1958) and Derwesh (1965); Europe (Rasmont et al., 1995). 
Anthophora fulvitarsis Brullé, 1832

Global distribution: Iraq (Khalaf, 1958); Austria, France, Greece, Hungary, Italy, Portugal, Romania, Spain, Ukraine (Rasmont and Dehon, 2015 b).

Anthophora sulaimanensis (Mawlood \& Amin, 2017)

Global distribution: Iraq (Mawlood and Amin, 2017).

Apis florea Fabricius, 1787

Global distribution: Iraq (Glaiim, 1992); Iran; Israel, UAE, Saudi Arabia, Ethiopia, Sudan, Pakistan, India, Sri Lanka, China, Thailand, Vietnam, Singapore and Indonesia (Ascher and Pickering, 2018).

Apis mellifera Linnaeus, 1758

Materials Examined (118 workers): Baghdad province: Jaddria, 11, 29.III.2017, 13, 14.IV.2017; Al Taji, 10, 22.IV.2017; Al Radhwania, 7, 3.V.2017. Wasit province: Al-Suwaira, 13, 30.VI.2017; Al-Zubaidiya, 15, 1.IX.2017, 12, 2.IX.2017, 3, 3.IX.2017. Babylon province: Al Qasim, 16, 2.IX.2016; Shomali, 3, 3.IX.2017. Maysan province: Hawizeh Marshes, Umm An-Ni'aaj, 9, 9.III.2017. Diyala province, Baqubah, 6, 18.XII.2017.

Global distribution: Cosmopolitan except for Antarctica (Mortensen et al., 2017)

Bombus fervidus (Fabricius, 1798)

Global distribution: El - Haidari et al. (1971) was listed to Iraq; although this species is native in North America: Canada, Mexico and United States (Hatfield et al., 2015a).

Bombus vosnesenskii Radoszkowski, 1862

Global distribution: El - Haidari et al. (1971) listed this species to Iraq; although it is native in Canada, Mexico and United States (Hatfield et al., 2015b).

Certaina laevifrons Morawitz, 1894

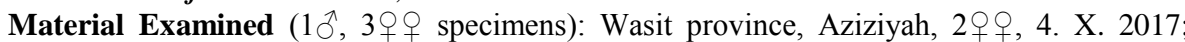
Baghdad province; Bab Al-Mudham, 1ㅇ, 29.IX.2017. Kerbela province, Kerbela, $1 \delta^{\Uparrow}$, 27.VII.2017.

Global distribution: Iraq (Derwesh, 1965); Turkmenistan, Central Asia, Southern of Iran to northern of Kazakhstan and from Caspian Sea to Kyrgyzstan (Terzo and Rasmont, 2011).

Ceratina nigrolabiata Friese, 1896

Global distribution: Iraq (Derwesh, 1965); Turkey (Terzo and Rasmont, 2011); South and Central Europe from Portugal to Greece, including European part of Russia; Azerbaijan, Georgia, Syria (Ascher and Pickering, 2018).

Ceratina schwarzi Kocourek, 1998

Global distribution: Iraq, Greece, Cyprus, Turkey, Syria, Iran and Israel (Grace, 2010).

Certaina tibialis Morawitz, 1895

= Ceratina ahngeri Kokujev, 1905

Global distribution: Iraq (Derwesh, 1965); Israel, Turkey, Syria, Iran, Azerbaijan, Tajikistan, Turkmenistan (Terzo, 1998).

Eucera bidentata Pérez, 1887

Material Examined ( $1 \hat{\delta}, 1$ ㅇ specimens): Baghdad province: Jaddria, 11.IX.2017.

Global distribution: Iraq (Derwesh, 1965); Greece on Lesbos and Cyprus (Grace, 2010). 
Razzaq Shalan Augul

Eucera clypeata Erichson, 1835

Global distribution: Iraq, Greece, Turkey, Syria, Israel, Palestine, Jordan, Iran and North Africa (Grace, 2010).

Eucera cypria Alfken, 1933

Global distribution: Iraq, Greece and Cyprus (Grace, 2010).

Eucera distinguenda (Morawitz, 1875)

= Tetralonia distinguenda Morawitz, 1875

Global distribution: Iraq (Derwesh, 1965); India, Kazakhstan, Pakistan, Turkmenistan (Insectoid.info, 2018).

Eucera alborufa (Radoszkowski, 1871)

=Tetralonia radoszkowskii Morawitz,1875

Global distribution: This species was listed to Iraq by Khalaf and Al-Omar (1974) under the name Tetralonia radoszkowskii Mor.; but there is no information about this species globally.

Eucera longicornis Linnaeus, 1758

Global distribution: Iraq (Derwesh, 1965); Europe (excluding the Far North) and Transcaucasia (Aliyev and Maharramov, 2015).

Eucera tibialis (Morawitz, 1837)

Global distribution: Iraq and Turkey (Grace, 2010).

Nomada basalis Herrich-Schaeffer, 1839

Global distribution: Iraq, Greece, Syria, Israel, Palestine, Turkey and Iran (Grace, 2010).

Nomada collarae Schwarz, 1964

Global distribution: Iraq and Turkey (Grace, 2010).

Nomada fenestrata Lepeletier, 1841

Global distribution: Iraq, Turkey, Israel, Jordan, Iran and Egypt (Grace, 2010); Pakistan, Tunisia, Morocco, Canary Islands, Spain and France (Ascher and Pickering, 2018).

Nomada fucata Panzer, 1798

Global distribution: Iraq (Derwesh, 1965); North east turkey (Grace, 2010); Austria, Belgium, Czech Republic, France, Germany, Poland, Greece, Italy, Kazakhstan, Spain, Sweden, United Kingdom and Denmark; Africa: Egypt; Asia: Iran, Israel, Kyrgyzstan (Insectoid.info, 2018).

Nomada mauritanica Lepeletier, 1841

Global distribution: Iraq, Greece, Cyprus, Turkey and Israel (Grace, 2010).

Nomada tigridis Morice, 1921

Global distribution: Iraq (Derwesh, 1965). 
Pasites maculates Jurine, 1807

Global distribution: Iraq (Khalaf and Al-Omar, 1974); Algeria, Cyprus, Czech Republic, France, Slovakia, Italy, Greece, Hungary, Austria, Bulgaria, Spain, China, Iran, Israel, Pakistan and South Korea (Inectoid.Info, 2018).

Thyreus ramosus (Lepeletier, 1841)

=Crocisa ashabadensis Radoszkowski, 1893

Global distribution: In Iraq this species was listed by Derwesh (1965) under the name of Crocisa ashabadensis Radoszkowski; Central and Southern Europe, northeast Africa, Arabia, west Asia, Himalaya and China (Beaumont, 1939; Rasmont, 2014).

Tetraloniella glauca (Fabricius, 1775)

Global distribution: In Iraq this species was listed by Grace (2010) under the name Tetralonia olivieri (lepeletier, 1841); Iran, Cyprus and Turkey (Ascher and Pickering, 2018).

Thyreomelecta dimidiatipuncta (Spinola, 1838)

Global distribution: Iraq, Libya, Egypt (Grace, 2010).

Xylocopa aestuans (Linnaeus, 1758)

Global distribution: In Iraq this species was listed by Khalaf and Al-Omar (1974); globally, it distributes in United Arab Emirates (Harten, 2005); Saudi Arabia (Hannan et al., 2012); Southeast Asia, Indochina, the Malay Peninsula and Indonesia (Pauly, 2016).

Xylocopa fenestrata (Fabricius, 1798)

Material Examined $(2 \hat{\jmath} \hat{\jmath}, 9 ㅇ ㅜ$ specimens): Baghdad province: Bab Al-Muadham, $1 \hat{\jmath}$, 2웅, 13.VI.2016; 1 $\hat{\jmath}, 4$ 우, 11.VIII.2017. Wasit province: Al-Zubaidiya, 2웅, 3. IX.2017. Maysan province: Hawizeh Marshes, Umm An-Ni'aaj, 19, 14.III.2017.

Global distribution: Iraq (Derwesh, 1965); Turkey (Warncke, 1982); Afghanistan, Burma, China, India, Iran, Madagascar, Mauritius, Nepal, Pakistan, Sri-Lanka and Reunion (Ascher and Pickering, 2018).

Xylocopa pubescens Spinola, 1838

Global distribution: Iraq (Swailem et al., 1974); Afghanistan, Algeria, Burma, Egypt, Ethiopia, India, Iran, Israel, Morocco, Nepal, Pakistan, Turkey, Syria, Senegal, Sudan, Kenya, Mozambique and Tanzania (Warncke, 1982; Ascher and Pickering, 2018).

Xylocopa olivieri Lepeletier, 1841

Global distribution: Iraq (Derwesh, 1965); Turkey (Warncke, 1982); Israel (Guershon and Ionescu-Hirsch, 2012); Albania, Azerbaijan, Greece, Crete, Cyprus, Iran, Kyrgyzstan, Macedonia, Syria and Turkmenistan (Ascher and Pickering, 2018).

Xylocopa rufa Friese, 1901

Global distribution: Iraq (Derwesh, 1965); Caucasus, Turkestan, Pakistan, Sudan, Israel and Iran (Warncke, 1982); Armenia, Kyrgyzstan, Tajikistan, Turkmenistan, India and China (Ascher and Pickering, 2018).

Xylocopa violacea (Linnaeus, 1758)

Global distribution: Iraq (Swailem et al., 1974); Europe, North Africa and western Asia (Warncke, 1982). 
Razzaq Shalan Augul

Family, Colletidae

Colletes nanus Friese, 1898

Global distribution: Iraq (Derwesh, 1965); Egypt, Jordan, Israel, Libya and Syria (Grace, 2010).

Hylaeus cornutus Curtis, 1831

=Prosopis cornutus $\mathrm{Sm}$.

Global distribution: West and Central Asia: Iraq, Caucasus, Turkey, Israel, Iran and Turkestan; Great Britain, Denmark; North Africa: Morocco, Algeria and Egypt (Celary and Dylewska 1988). It distributes also in Armenia, Azerbaijan, Syria and Russia (Proshchalykin and Dathe, 2017).

Hylaeus klugii (Friese, 1898)

Global distribution: Iraq, Egypt, Iran, Israel and Khuzestan (Grace, 2010); according to the previous author, the subspecies of $H$. klugii mesopotamae (Warncke, 1992) is described in Iraq.

Hylaeus nyroca (Warncke, 1992)

Global distribution: Iraq (Grace, 2010).

Hylaeus pictus (Smith, 1853)

Global distribution: In Iraq this species is listed under the name of Hylaeus damascenus magretti by Derwesh (1965); also it distributes in Turkey, Israel and Iran (Grace, 2010).

Hylaeus trinotata Pérez, 1895

Global distribution: Iraq, Turkey; in Iraq the subspecies of $H$. $t$. mesopotamica collected from Sumel district, Dohuk (Grace, 2010).

\section{Family: Halictidae}

Ceylalictus punjabensis (Cameron, 1907)

=Nomioides excellens Saunders, 1908

Global distribution: In Iraq the species was listed under the name of Nomioides excellens by Derwesh (1965); Iran, India, Egypt, Saudi Arabia, Cape Verde, Jordon, Israel, Morocco, Senegal, Djibouti, Tunisia, Afghanistan, Niger, UEA, Mauritania, Pakistan, Sudan, Kenya and Libya (Ascher and Pickering, 2018).

Ceylalictus variegatus (Olivier, 1789)

= Andrena variegata Olivier, 1789

= Nomioides variegata (Olivier, 1789)

Global distribution: This species is listed in Iraq under the name Nomioides variegata (Olivier, 1789) by Derwesh (1965); Eastern Europe, Cyprus, Mediterranean Basin, Middle East, Sardinia and Sicily (Balzan et al., 2016).

Dufourea nodicornis (Warncke, 1979)

Global distribution: Iraq, Egypt, Libya, Israel, Jordan and Syria (Grace, 2010).

Halictus fatsensis Blüthgen, 1936

Global distribution: Iraq, Cyprus, Israel, Jordan and Turkey (Grace, 2010); Egypt (Ebmer, 2014). 
Halictus cephalicus Morawitz, 1874

Global distribution: Iraq, Afghanistan, Iran, Israel, Syria, Russia, Southeastern Europe, Caucasus, Turkey (Astafurova et al., 2017).

Halictus lucidipennis Smith, 1853

Halictus varipes Morawitz, 1876

Global distribution: Derwesh (1965) listed this species in Iraq under the name Halictus varipes; Pauly et al. (2002) also listed it in: Algeria, Cape Verde, Chad, Egypt, Ethiopia, Morocco, Tunisia, Libya, Senegal, Gambia, Mali, Burkina-Faso, Niger, Cameroon, Sudan, Eritrea, Djibouti, Kenya, Arabia, Oman, Yemen, Jordan, Iran, Turkey, Israel, Turkmenistan, Uzbekistan, Tajikistan, Kyrgyzstan, Kazakhstan, Afghanistan, Bhutan, Burma, India, Pakistan, Sri Lanka, Nepal, Thailand and China.

Halictus mongolicus Morawitz, 1880

Global distribution: Iraq (Derwesh, 1965); China, Turkistan and Mongolia (Ze-Qing et al., 2004).

Halictus scabiosae (Rossi, 1790)

Global distribution: Iraq (Derwesh, 1965); Greece and Turkey (Grace, 2010); Western Palaearctic with Western Mediterranean, from Morocco to Rhodes and Bosphorus, from the Atlantic Ocean to the north, to Belgium and Channel Island Jersey (Ebmer, 1988); in addition, Balzan et al. (2016) listed this species in Sardinia and Sicily.

Halictus senilis (Eversmann, 1852)

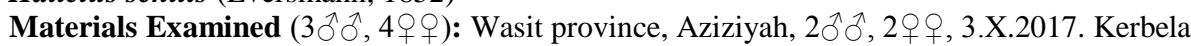
province, Kerbela, 1ð, 2 우, 27.VII.2017.

Global distribution: Iraq (Khalaf, 1958); Turkey, Jordan and Libya (Grace, 2010); Spain, Tunisia, Egypt, Iran, Mongolia, Eurasia from southeast Russia to Turkestan, Afghanistan, Pakistan, Israel (Pauly et al., 2016).

Halictus tectus Radoszkowski, 1875

=Halictus sogdianus Morawitz, 1876

Global distribution: In Iraq this species is listed by Derwesh (1965) under the name of Halictus sogdianus Morawitz; Eurasia from southern France, also Iberia to Mongolia (Ebmer, 1988); Greece (Grace, 2010).

Halictus tetrazonianellus Strand, 1909

Halictus leucognathus Morice, 1921

Global distribution: In Iraq this species is listed under the name of Halictus leucognathus Morice, 1921 (Derwesh, 1965); Bulgaria, Greece, Moldova, Ukraine, Turkey to Turkmenistan, Israel and Jordan (Ebmer, 2014).

Halictus vestitus Lepeletier, 1841

Global distribution: Iraq (Derwesh, 1965); China; Mongolia; former USSR; France and Austria (Ze-Qing et al., 2007).

Lasioglossum carneiventre (Dours, 1872)

Global distribution: Iraq, Algeria, Egypt, Iran, Israel and Syria (Ebmer, 2014). 
Lasioglossum aegyptiellum (Strand 1909)

Global distribution: In Iraq the checklist of Derwesh (1965) listed this species under the name of Halictus platysectus Dours.; according to Ebmer (1988) this species distributes in Mediterranean-West Asian, from Morocco to Iran and Turkmenia; also Pauly (2016) listed this species for Croatia, Minor Asia to Iraq and Iran, Israel and Egypt,

Lasioglossum leucozonium (Schrank, 1781)

= Halictus leucozonius Kirby

Materials Examined (1乞): Wasit province, Al Zubaidiya district, 1§ึ, 20.X.2017.

Global distribution: In Iraq this species registered as Halictus leucozonius Kirby by Derwesh (1965). Holarctic region (McGinley, 1986; and Ebmer, 1988); Greece, Turkey, Iran, Cyprus (Grace, 2010).

Lasioglossum malachurum (Kirby, 1802)

$=$ Halictus longulus Smith, 1848

= Halictus malachurus Kirby

Global distribution: Derwesh (1965) listed this species in Iraq under the name of Halictus longulus Smith; West-Palaearctic: from the Azores to Iran, from Morocco north to England and Denmark (Ebmer, 1988); in addition Grace (2010) listed this species in: Greece, Cyprus, Turkey, Israel, Palestine, Jordan and Egypt

Lasioglossum mandibulare (Morawitz, 1866)

Global distribution: Iraq, France, Portugal, Turkmenistan, Kazakhstan, Israel, Romania, Austria, Ukraine (Ebmer, 2014)

Lasioglossum marginatum (Brullé 1832)

=Halictus kervilleanus Perez, 1910

Global distribution: This species is listed in Iraq by Derwesh (1965) under the synonym; Greece, Cyprus, Turkey, Syria, Lebanon, Israel, Jordan and Iran (Grace, 2010).

Lasioglossum picipes (Morawitz, 1876)

=Halictus amaranus Morice, 1921

Global distribution: This species is listed in Iraq by Derwesh (1965) under the synonym of Halictus amaranus; Israel and Iran (Grace, 2010).

Lasioglossum politum Schenck 1853

Global distribution: Iraq, Greece, Turkey, Iran, Israel, Jordan and Egypt (Grace, 2010).

Lasioglossum scheherezade Ebmer, 2000

Global distribution: Iraq (Grace, 2010).

Lasioglossum vagans (Smith, 1857)

= Halictus chaldaeorum Morice, 1921

Global distribution: This species is registered in Iraq by Derwesh (1965) under the name Halictus chaldaeorum; Turkey, Lebanon, Jordan, Israel and Egypt (Grace, 2010).

Nomiapis bispinosa (Brullé, 1832)

Materials examined ( $1 \delta^{\hat{~}}$ specimen): Maysan province, Hawizeh Marsh, Umm An-Ni'aaj, $1 \delta^{\lambda}$, 9.VI.2015.

Global distribution: This species is registered in Iraq under the name of Nomia rufiventris, Spinola (Derwesh, 1965).Crete, Cyprus, Turkey and Egypt (Grace, 2010); Portugal, Spain, 
Italy, Southern France, Sardinia, former Yugoslavia, Greece, Hungary, southern Russia and Pakistan (Michez et al., 2013).

Nomioides ino (Nurse, 1904)

Global distribution: Iraq, Iran, Turkey and Jordan (Grace, 2010); Turkmenistan, Uzbekistan, Tajikistan, Mongolia (Pauly, 2017).

Nomioides turanicus Morawitz, 1876

Global distribution: Iraq, Egypt, Turkey and Iran (Grace, 2010).

Pseudapis edentata (Morawitz 1876)


9.VI.2015.Wasit province, Al-Shahabi, 1 $\jmath^{2}, 4$ 우, 10.VI.2015.

Global distribution: In Iraq, Derwesh (1965) listed this species under the name Nomia edentata Morawitz; Turkey, Iran and Egypt (Grace, 2010).

Pseudapis innesi (Gribodo, 1894)

Materials examined (2우): Maysan province, Hawizeh Marsh, Umm An-Ni'aaj, 9.VI.2015.

Global distribution: Iraq and Egypt (Grace, 2010).

Pseudapis nilotica (Smith, 1875)

Global distribution: In Iraq, it was registered by Khalaf and Al-Omar (1974) under the name of Nomia savignyi Kohl; also distributes from Morocco and Mauritania to Pakistan; Egypt, Jordan, Israel and Iran (Grace, 2010)

\section{Sphecodes sp.}

Material Examined (2우): Baghdad province; Bab Al-Muadham, the specimens collected at 22.VI.2017.

Global distribution: The genus of Sphecodes Latreille, 1804 distributes in Holarctic Region and North to the Subarctic (Astafurova and Proshchalykin, 2014).

\section{Family: Megachilidae}

Anthidium florentinum (Fabricius, 1775)

Global distribution: Iraq (Khalaf and Al-Omar, 1974); Greece, Macedonia, Crete, Turkey, Iran and Israel (Grace, 2010).

Anthidium tessellatum Klug, 1832

Global distribution: In Iraq this species is listed by Derwesh (1965); Egypt (Warncke, 1980); Israel, Jordon, Lebanon (Grace, 2010).

Anthidiellum strigatum (Panzer, 1805)

Global distribution: In Iraq this species is listed under the name of Anthidium strigatum Panzer by Derwesh (1965); Central Asia, Cyprus, Europe, Greece, Iran, Lebanon, North Africa, Palestine, Russia, Syria, Turkey (Warncke, 1980); Israel and Libya (Grace, 2010); the last author is listed the subspecies A. s. crassepunctatum Popov, 1935 for Iraqi fauna.

Coelioxys afra Lepeletier, 1841

Global distribution: Iraq (Derwesh, 1965); Africa (Pasteels, 1977); Algeria, Egypt, Kyrgyzstan, Morocco, Russia, Tunisia, Turkmenistan, Uzbekistan (Warncke, 1992); South, Eastern and Central Europe, UK, Asia Minor (Banaszak and Romasenko, 1998); Western 
Razzaq Shalan Augul

Europe to China and Indonesia (Proshchalykın and Lelej, 2004); Greece, Cyprus, Turkey, Israel and Egypt (Grace, 2010) and Iran (Khaghaninia et al., 2010).

Coelioxys coturnix Pérez, 1884

Global distribution: Iraq (Derwesh, 1965); Palaearctic region (Ortiz-Sánchez, 2014). It was introduced to the USA.

Coelioxys decipiens Spinola, 1838

Global distribution: Iraq (Derwesh, 1965); also this species distributed from north Africa towards Cyprus, Crete, Turkey, Asia Minor and Central Asia, until the Himalayas (Ornosa et al., 2007, Ortiz-Sánchez et al., 2009, Grace, 2010).

Coelioxys haemorrhoa Forster, 1853

Materials examined ( $1 \hat{\delta}, 4 \circ+$ specimens): Maysan province: Hawizeh Marshes, Umm AnNi'aaj, 1ㅅ, 3 우, 9.VI.2015; Baghdad province: Bab Al-Muadham, 1ㅇ, 10.IX.2017.

Global distribution: Iraq (Derwesh, 1965); also distributes in Southern Europe, from the Iberian Peninsula to Austria; North Africa to Central Asia (Ornosa et al., 2007).

Coelioxys obtusa Pérez, 1884

Global distribution: Iraq (Derwesh, 1965); Turkey (Özbek and van der Zanden, 1994); Egypt, Morocco, France, Greece, Croatia, Caucasus, Spain Italy, Poland, Iran, Turkmenistan (Ascher and Pickering, 2018).

Coelioxys ruficauda Lepeletier, 1841

Global distribution: Iraq, Crete, Turkey and Egypt (Grace, 2010).

Megachile apicalis Spinola, 1808

Materials examined: Maysan province, Hawizeh Marsh, Umm An-Ni'aaj, 1 9 , 9.VI.2015.

Global distribution: Iraq (Khalaf and Al-Omar, 1974); Eurasia, United States (James and Pitts-Singer, 2008); Cyprus, Turkey, Israel, Greece, Rhodes, North Africa although not reported for Egypt and Libya (Grace, 2010).

Megachile argentata (Fabricius, 1793)

Materials examined $(3 \hat{\partial} \hat{\partial}, 5 ㅇ+$ ): Baghdad province: Al-Madaen, $1 \hat{\delta}$ and 4 우우,

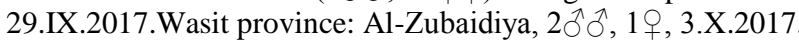

Global distribution: Iraq (Derwesh, 1965); Europe (Özbek and van der Zanden, 1994);

North-Eastern China, Caucasus, North Africa, North America (Proshchalykin, 2007); Syria (Grace, 2010) Algeria and Hungary (Balzan et al., 2016).

Megachile babylonica Rebmann 1970

Global distribution: Iraq (Grace, 2010).

Megachile concinna Smith, 1879

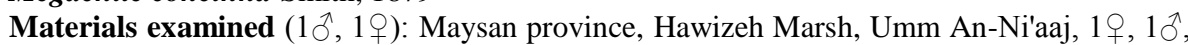
9.VI.2015

Global distribution: Iraq (Insectoid.info, 2018); Holarctic region (Ascher and Pickering, 2018). 
Megachile farinosa (Smith, 1853)

Global distribution: Grace (2010) listed this species in Iraq under the name of Chalicodoma farinosa (Smith, 1853); also it distributed in Egypt, Turkey (Grace, 2010; Ascher and Pickering, 2018).

Megachile flavipes (Spinola, 1838)

Global distribution: Iran (Morice, 1921), Iraq (Derwesh, 1965) and Turkey (Warncke, 1992).

Megachile minutissima Radoszkowski 1876

Global distribution: Iraq (Derwesh, 1965); Egypt, Turkey and Israel (Grace, 2010).

Megachile rotundata (Fabricius, 1787)

Materials examined $(1 \hat{\jmath}, 2+$ 우): Maysan province, Hawizeh Marsh, Umm An-Ni'aaj, 2 우, 9.VI.2015; Wasit province, Kut, 1̊̊, 27.V.2017.

Global distribution: Iraq, Iran, Greece, Cyprus and Turkey (Grace, 2010).

Megachile schnabli Radoszkowski, 1893

Global distribution: Iraq (Derwesh, 1965); Iran, Turkmenistan and Tajikistan (Ascher and Pickering, 2018).

Megachile squamosa Rebmann, 1970

Global distribution: Iraq (Grace, 2010).

Megachile striatella Rebmann, 1968

Global distribution: Egypt, Iraq, Iran, Greece and Libya (Grace, 2010).

Osmia indigotea Morawitz, 1875

Global distribution: Iraq (Derwesh, 1965).

Osmia brevicornis (Fabricius, 1798)

= Osmia panzeri Morawitz, 1869

Global distribution: In Iraq this species is listed by Derwesh (1965) under the synonym; Romania (Ban-Calefariu, 2009).

Protosmia paradoxa (Friese 1899)

Global distribution: In Iraq, this species is listed by Khalaf and Al-Omar (1974) under the synonym of Osmia paradoxa Fr.; Greece, Cyprus, Turkey, Lebanon, Palestine, Israel, Jordan and Syria (Grace, 2010).

Stelis phaeoptera (Kirby, 1802)

Global distribution: Iraq (Derwesh, 1965); Greece, Israel, Egypt and Libya (Greece, 2010).

Stelis signata (Latreille, 1809)

Global distribution: Iraq (Derwesh, 1965); Cyprus, Greece, Israel, Lebanon and Turkey (Grace, 2010); in addition to, the last author listed the subspecies S. s. eremica Alfken 1938 in Iraq. 


\section{LITERATURE CITED}

Ahmed, H. 2017. Taxonomic study of bees (Hymenoptera: Apoidea) in some localities of Kurdistan region-Iraq. Msc. in plant protection, College of Agriculture, Salahaddin University, Erbil, Iraq. (Abstract)

Aliyev, K. A. and Maharramov, M. M. 2015. Contribution on the study of Eucera Scopoli (Hymenoptera: Apidae) from Nakhchivan Autonomous Republic (Azerbaijan). Stuttgarter Beiträge zur Naturkunde A, Neue Serie 8: 247-250.

Amiet, F., Herrmann, H., Müller, A. and Neumeyer, R. 2004. Apidae 4: Anthidium, Chelostoma, Coelioxys, Dioxys, Heriades, Lithurgus, Megachile, Osmia, Stelis. Fauna Helvetica, $9: 1-273$.

Ascher, J. S. and Pickering, J. 2018. Discover Life's bee species guide and world checklist. Available at: http://www.discoverlife.org (Accessed at: 2.02.2018)

Astafurova, Y. V. and Proshchalykin M. Y. 2014. The bees of the genus Sphecodes Latreille 1804 of the Russian Far East, with key to species (Hymenoptera: Apoidea: Halictidae) Zootaxa, 388: 501-528.

Astafurova, Y. V., Proshchalykin, M. Y. and Maharramov, M. M. 2017. Contribution to the knowledge of the Seladonia Robertson and Vestitohalictus Blüthgen Hymenoptera: Halictidae: Halictus Latreille). Linzer Biologische Beiträge, 49(1): 377-386.

Augul, R. S. 2016. Insect pollinators in different regions of Iraq. Journal of Entomology and Zoology Studies, 4(2): 391-402.

Baldock, D. 2014. A provisional list of the wasps and bees of Mallorca, Balearic Islands, Spain (Hymenoptera Aculeata: Chrysidoidea, Scolioidea, Vespoidea, Apoidea). Entomofauna, 35(16): 333-404.

Balzan, M. V., Rasmont, P., Kuhlmann, M., Dathe, H. H., Pauly, A., Patiny, S., Terzo, M. and Michez, D. 2016. The bees (Hymenoptera: Apoidea) of the Maltese Islands. Zootaxa, 4162(2): 225-244.

Banaszak, J. and Romasenko, L. 1998. Megachilid bees of Europe (Hymenoptera, Apoidea, Megachilidae). Bydgoszcz University, Bydgoszcz, 239 pp.

Ban-Calefariu, C. 2009. Checklist of Megachilidae (Hymenoptera: Apoidea) of the Romanian fauna. Travaux du Muséum National d'Histoire Naturelle "Grigore Antipa", 52: 303-311.

Beaumont, J. De. 1939. Les Crocisa de la faune française (Hym., Apidae). Annales de la Société entomologique de France, 108: 161-171.

BWARS (Bees, Wasps and Ants Recording Society). 2012. Chapter 5-The Genera, V 3 doc/rev.10/5/12, 77pp. (Available at: http://www.bwars.com/sites/www.bwars.com/files/diary_downloads/Britain\%27s_Bee s_Chapter_5_the_Genera.pdf) 
Celary, W. and Dylewska, M. 1988. Colletidae (Hymenoptera, Apoidea) Polski. Polskie Pismo entomologiczne, 58: 359-382.

Derwesh, A. I. 1965. A preliminary list of identified insects and arachnids of Iraq. Director General Agriculture Research Projections Baghdad, Bulletin, 112:121-123.

Eardly, C. D., Kuhlmann, M. and Pauly, A. 2010. The bee genera and subgenera of subSaharan Africa. ABC Taxa, 7: 1-138.

Ebmer, A. W. 1988. Kritische Liste der nicht-parasitischen Halictidae Österreichs mit Berücksichtigung aller mitteleuropäischen Arten (Insecta: Hymenoptera: Apoidea: Halictindae). Linzer biologische Beiträge, 20: 527-711.

Ebmer, A. W. 2014. Die nicht-parasitischen Halictidae der Insel Zypern im Vergleich zu Kreta mit einer Monographie der Lasioglossum bimaculatum-Artengruppe und einer Übersicht der Halictus nicosiae-Untergruppe (Insecta: Hymenoptera: Apoidea: Halictidae)._Linzer biologische Beiträge, 46(1): 291-413.

El-Haidari, H., Fattah, Y. M. and Sultan, J. A. 1971. Contribution to the insect fauna of Iraq (part 3). Ministry of Agricultural, Iraq, Bulletin, No.3: 20 pp.

Gauld, I. and Bolton, B. 1988. The Hymenoptera. British Museum (Natural History), Oxford University Press, 332 pp

Glaiim, M. K. 1992. First definitive record of Apis florea in Iraq. Beekeeping and Development Bees for Development Journal, 24: 3. Available at: http://www.beesfordevelopment.org/documents/f/first-definitive-record-of-apis-floreain-iraq/

Grace, A. 2010. Introductory biogeography to bees of the Eastern Mediterranean and Near East. Bexhill Museum, First Edition, Sussex, United Kingdom, 284pp.

Grimaldi, D. A. 1999. The co-radiations of pollinating insects and angiosperms in the Cretaceous. Annals of the Missouri Botanical Garden, 86: 373-406.

Guershon, M. and Ionescu-Hirsch, A. 2012. A review of the Xylocopa species (Hymenoptera: Apidae) of Israel. Israel Journal of Entomology, 41-42:145-163.

Hannan, M. A., Alqarni, A. S., Owayss, A. A. and Engel, M. S. 2012. The large carpenter bees of central Saudi Arabia, with notes on the biology of Xylocopa sulcatipes Maa (Hymenoptera, Apidae, Xylocopinae). ZooKeys, 201: 1-14.

Harten, A. V. 2005. The Insects of the United Arab Emirates: A Checklist of published records. Dar Al Ummah, Abu Dhabi, UAE, 86 pp.

Hassan, S. H. 2007. Comparative study for some insect pollinators Apoidea that pollinated Alfalfa Medicago sativa in Babylon. A thesis in Ph. D. in Biology/Zoology, College of Science, Al-Mustansiriya University, 113pp.

Hatfield, R., Jepsen, S., Thorp, R., Richardson, L., Colla, S. and Foltz Jordan, S. 2015a. Bombus fervidus. The IUCN Red List of Threatened Species 2015: 
Razzaq Shalan Augul

e.T21215132A21215225. http://dx.doi.org/10.2305/IUCN.UK.20154.RLTS.T21215132A21215225.en. (Downloaded on 20 January 2018).

Hatfield, R., Jepsen, S., Thorp, R., Richardson, L. and Colla, S. 2015b. Bombus vosnesenskii. The IUCN Red List of Threatened Species 2015: e.T44938235A46440326. http://dx.doi.org/10.2305/IUCN.UK.2015-2.RLTS.T44938235A46440326.en. Downloaded on 20 January 2018.

Huan-li, X. and Tadauchi, O. 2008.The subgenera Margandrena, Leimelissa, Stenomelissa and Zonandrena of the genus Andrena of Eastern Asia (Hymenoptera, Andrenidae). Journal of Faculty of Agriculture, Kyushu University, 53(1):63-66.

Insectoid.info. 2018. Available at: http://insectoid.info/insecta/hymenoptera/apidae_family/

James, R. R. and Pitts-Singer, T. L. 2008. Bee pollination in agricultural ecosystems. New York: Oxford University Press, 232 pp.

Karunaratne, W. A. I. P. and Edirisinghe, J. P. 2008. Keys for the identification of common bees of Sri Lanka. Journal of the National Science Foundation of Sri Lanka, 36 (1): 69-89.

Khaghaninia, S., Güler, Y. and Mousavi, M. 2010. Megachilids bees (Hymenoptera: Apoidea) of Aynali forests with four new records for Iran. Munis Entomology and Zoology, 5, suppl.: 890-895.

Khalaf, K. T. 1958. Some Hymenoptera and Coleoptera from Iraq. Iraq Natural History Museum, Publication, 14: 1-3.

Khalaf, A. N. and Al - Omar, M. A. 1974. A second list of insects from Iraq. Biological. Research Centre, Publication No. 2: 41pp.

Klein, A. M., Vaissière, B. E. and Cane, J. H. 2007. Importance of pollinators in changing landscapes for world crops. Proceedings of the Royal Society B, 274 (1608): 303-313.

Kuhlmann, M., Ascher, J. S., Dathe, H. H., Ebmer, A. W., Hartmann, P., Michez, D., Müller, A., Patiny, S., Pauly, A., Praz, C., Rasmont, P., Risch, S., Scheuchl, E., Schwarz, M., Terzo, M., Williams, P. H., Amiet, F., Baldock, D., Berg, Ø., Bogusch, P., Calabuig, I., Cederberg, B., Gogala, A., Gusenleitner, F., Josan, Z., Madsen, H. B., Nilsson, A., Ødegaard, F., Ortiz- Sanchez, J., Paukkunen, J., Pawlikowski, T., Quaranta, M., Roberts, S. P. M., Sáropataki, M., Schwenninger, H.-R., Smit, J., Söderman, G. and Tomozei, B. 2015. Checklist of the Western Palaearctic Bees (Hymenoptera: Apoidea: Anthophila). Available from: http://westpalbees.myspecies.info (Accessed 2 February 2018).

Mawlood, N. A. and Amin, H. M. 2017. New species of the bee, Anthophora Latreille, 1803 (Hymenoptera: Apidae) from Kurdistan region-Iraq. Kurdistan Journal of Applied Research, 2(1):65-67.

McGinley, R. J. 1986. Studies of Halictinae (Apoidea: Halictidae), I: Revision of New World Lasioglossum Curtis. Smithsonian Contributions to Zoology, 428: 1-294. 
Study on Diversity of Bees (Hymenoptera, Apoidea)

Michener, C. D. 1993. Series Apiformis. In: Goulet, H. and Huber, J. T. (eds) Hymenoptera of the world; an identification guide to families. Agriculture Camada Publication, pp 307-357.

Michener, C. D. 2000.The bees of the World. Baltimore \& London: J. Hopkins University Press, xiv +913 pp.

Michener, C. D. 2007.The bees of the world, second edition. The Johns Hopkins University Press. USA, 951pp.

Michez, D., Nieto, A. and Pauly, A. 2013. Nomiapis bispinosa. The IUCN Red List of Threatened Species 2013: e.T13339763A13340250. (Downloaded on 25 January 2018)

Morice, F. D. 1921. Annotated lists of aculeate Hymenoptera (except Heterogyna) and Chrysids recently collected in Mesopotamia and north-west Persia. II. Journal Bombay Natural History Society, 28: 192-99.

Morse, R. A. and Calderone N. W. 2001. The value of honey bees as pollinators of US crops in 2000. Bee Culture, 128(3):1-15.

Mortensen, A. N., Schmehl, D. R. and Ellis, J. 2017. European honey Bee Apis mellifera and subspecies Linnaeus (Insecta: Hymenoptera: Apidae). UF/IFAS Extension, University of Florida, EENY568, 6pp. (Available at: http://edis.ifas.ufl.edu/pdffiles/IN/IN100500.pdf)

Nadimi, A., Talebi, A. A. and Fathipour, Y. 2013. A preliminary study of the cleptoparasitic bees of the genus Coelioxys (Hymenoptera: Megachilidae) in northern Iran, with six new records. Journal of Crop Protection, 2 (3): 271-283.

O'Grady, J. H. 1987. Market failure in the provision of honeybee pollination: a heuristic investigation. M.Sc Thesis, University of Vermont.

Ornosa, C., Ortiz-Sánchez, F. J. and Torres, F. 2007. Catálogo de los Megachilidae del Mediterráneo occidental (Hymenoptera, Apoidea). II. Lithurgini y Megachilini. Graellsia, 63(1): 111-134.

Ortiz-Sánchez, F. J. 2014. Coelioxys coturnix. The IUCN Red List of threatened species 2014: e.T19199794A21142579. (Downloaded on 07 February 2018).

Ortiz-Sánchez, F. J., Torres, F. and Ornosa, C. 2009. Claves de identificación para las especies ibéricas del género Coelioxys Latreille, 1809 (Hymenoptera, Apoidea, Megachilidae). Graellsia, 65(2): 155-170.

Özbek, H. and van der Zanden, G. 1994. A preliminary review of the Megachilidae of Turkey. Part IV. Megachilini and Lithurgini (Hymenoptera: Apoidea). Turkiye Entomoloji Dergisi, 18:157-174.

Pasteels, J. J. 1977. Les Megachilini parasites (Coelioxys s. 1.) d'Afrique noire. Subdivision générique et subgénérique. Descriptions d'espèces nouvelles et rectifications de nomenclature (Hymenoptera, Apoidea, Megachilidae). Revue de Zoologie Africaine, 91: 161-197. 


\section{Razzaq Shalan Augul}

Pauly, A. 1999. Classification des Halictini de la région Afrotropicale (Hymenoptera, Apoidea, Halictidae). Bulletin de l'Institut Royal des Sciences Naturelles de Belgique, 69: 137-196.

Pauly, A. 2016. Les Xylocopa d'Afrique. Atlas Hymenoptera. Available at: http://www.atlashymenoptera.net/page.asp?id=84.

Pauly, A. 2017. The genus Nomioides Schenck, 1867. Available at: http://www.atlashymenoptera.net/page.asp?ID=96

Pauly, A., Pesenko, Y. and Radchenko, V. 2016. Les Halictus Latreille, 1804 d'Europe et du Basin Méditerranéen. Atlas Hymenoptera. Available at: http://www.atlashymenoptera.net/page.asp?id=70

Pauly A., Pesenko, Y. A. and La Roche, F. 2002. The Halictidae of the Cape Verde Islands (Hymenoptera Apoidea). Bulletin de l'Institut Royal des Sciences Naturelles de Belgique, Entomologie, 72: 201-211.

Pesenko, Y. A. 2006. Contributions to the halictid fauna of the Eastern Palaearctic Region: genus Lasioglossum Curtis (Hymenoptera: Halictidae, Halictinae). Zoosystematica Rossica, 15(1):133-166.

Proshchalykin, M. Yu. 2007. The bees of family Megachilidae (Hymenoptera, Apoidea) of Transbaikalia. Far Eastern Entomologist, 175:1-18.

Proshchalykin, M. Yu. and Dathe, H. H. 2017. New records of bees of the genus Hylaeus Fabricius (Hymenoptera: Colletidae) in the European part of Russia and North Caucasus. Proceedings of the Russian Entomological Society, 88(2): 61-65.

Proshchalykin, M. Yu. and Lelej, A. S. 2004. New and little known bees (Hym; Apidae) from the Russian Far East. Far Eastern Entomologist, 136: 1-10.

Rasmont, P. 2014. Atlas of the European Bees: genus Thyreus. Mons, Gembloux. Available at: http://www.zoologie.umh.ac.be//hymenoptera/page.asp?ID=258.

Rasmont, P. and Dehon, M. 2015a. Anthophora orientalis. The IUCN Red List of Threatened Species 2015: e.T63775308A64174276. Available at: http://www.iucnredlist.org/details/full/63775308/1. Downloaded on 22 January 2018

Rasmont, P. and Dehon, M. 2015 b. Anthophora fulvitarsis. The IUCN Red List of Threatened Species 2015: e.T19199302A21772812. Available at: http://www.iucnredlist.org/details/full/19199302/1. Downloaded on 19 January 2018

Rasmont, P., Ebmer, A. P., Banaszak, J. and van der Zanden, G. 1995. Hymenoptera Apoidea Gallica - Liste taxonomique des abeilles de France, de Suisse et du Grand-Duché de Luxembourg. Bulletin de la Société entomologique de France, 100: 1-98.

Robinson, W. S., Nowogrodski, R. and Morse, R. A. 1989. The value of honey bees as pollinators of US crops. American Bee Journal, 129(6, 7):411-423, 477-487. 
Study on Diversity of Bees (Hymenoptera, Apoidea)

Sakagami, S. F. and Ebmer, A. W. 1987. Taxonomic notes on oriental Halictine bees of the genus Halictus (subgen. Seladonia) (Hymenoptera Apoidea). Linzer Biologische Beiträge, 19: 301-357.

Salem, M. M. and El-Azab, S. A. 2017. Checklist with some taxonomic notes on the species of the family Megachilidae (Hymenoptera: Apoidea) recorded in Egypt. Egyptian Academic Journal of Biological Sciences, 10(1): 41-54.

Sheffield, C. S., Ratti, C., Packer, L. and Griswold, T. 2011. Leafcutter and mason bees of the Genus Megachile Latreille (Hymenoptera: Megachilidae) in Canada and Alaska. Canadian Journal of Arthropod Identification, 18: 1-107.

Swailem, S. M., Selim, A. A. and Amin, A. H. 1974. A contribution to the study of the insect fauna of Hammam Al-Alil, Part I. Mesopotamia Journal of Agriculture, 9(1-2): 119141.

Terzo, M. 1998. Annotated list of the species of the genus Ceratina (Latreille) occurring in the Near East, with descriptions of new species (Hymenoptera: Apoidea: Xylocopinae). Linzer biologische Beitrage, 30(2): 719-743.

Terzo, M. and Rasmont, P. 2011. Atlas of the European bees: genus Ceratina. STEP Project, Atlas Hymenoptera, Mons, Gembloux. (Available at: http://www.zoologie.umh.ac.be/hymenoptera/page.asp?ID=192.

Warncke, K. 1980. Die Bienengattung Anthidium Fabricius, 1804 in der Westpalaarktis und im turkestanischen becken. Entomofauna, 1 (10): 119-210.

Warncke, K. 1982. Die Holzbienen des Vorderen Orients (Hym., Apidae). Linzer biologische Beiträge,14(1): 23-37.

Warncke, K. 1992. Die Westpalaarktischen Arten der Bienengattung Coelioxys Latr. (Hymenoptera, Apidae, Megachilinae), Berlinische Gesellschaft Naturforschender Freunde, 53:31-77.

Warncke, K. and Scobiola-Palade, X. 1980. Données sur les Hyménoptéres Andrenidae (Apoidea) de Roumanie. Travaux du Museum National d'Histoire Naturelle "Grigore Antipa", 21: 163-175.

Ze-Qing, N., Yan-Ru, W. and Da-Wei, H. 2004. A taxonomic study on the subgenus Seladonia (Hymenoptera: Halictidae: Halictus) in China with a description of a new species. Zoological Studies 43 (4): 647-670.

Ze-Qing, N., Chao-Dong, Z., Yan- Zhou, Z., Yan-Ru, W. and Da-Wei, H. A 2007.Taxonomic study of the subgenus vestitohalictus of the genus Halictus (Hymenoptera, Halictidae, Halictinae) from China. Acta Zootaxonomica Sinica, 32 (1): 90-108. 
Bull. Iraq nat. Hist. Mus.

(2018) 15 (1): 57-75

دراسة التنوع في النحل (رتبة غشائية الأجنحة، فوق عائلة النحليات)

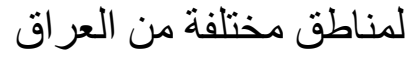

رزاق شعلان عكل

مركز بحوث ومتحف التأريخ الطبيعي العر اقي، جامعة بغداد

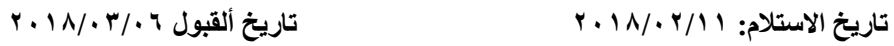

الخلاصة

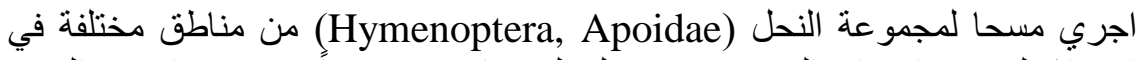

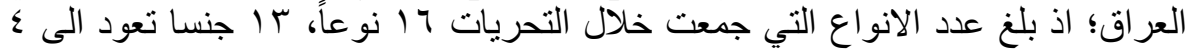

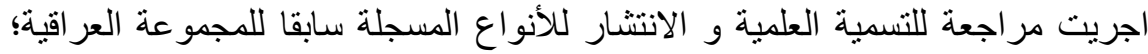



.Megachilidae و Halictidae ،Colletidae ‘Andernidae ‘Apidae 